\title{
Two Concepts of Basic Equality
}

\author{
Nikolas Kirby ${ }^{1}$
}

(C) The Author(s) 2017. This article is published with open access at Springerlink.com

\begin{abstract}
It has become somewhat a commonplace in recent political philosophy to remark that all plausible political theories must share at least one fundamental premise, 'that all humans are one another's equals'. One single concept of 'basic equality', therefore, is cast as the common touchstone of all contemporary political thought. This paper argues that this claim is false. Virtually all do indeed say that all humans are 'equals' in some basic sense. However, this is not the same sense. There are not one but (at least) two concepts of basic equality, and they reflect not a grand unity within political philosophy but a deep and striking division. I call these concepts 'Equal Worth' and 'Equal Authority'. The former means that each individual's good is of equal moral worth. The latter means that no individual is under the natural authority of anyone else. Whilst these two predicates are not in themselves logically inconsistent, I demonstrate that they are inconsistent foundation stones for political theory. A theory that starts from Equal Worth will find it near impossible to justify Equal Authority. And a theory that starts from Equal Authority will find any fact about the true worth of things, including ourselves, irrelevant to justifying legitimate action. This helps us identify the origin of many of our deepest and seemingly intractable disagreements within political philosophy, and directs our attention to the need for a clear debate about the truth and/or relationship between the two concepts. In short, my call to arms can be summed up in the demand that political philosophers never again be allowed to claim 'that all human beings are equals' full stop. They must be clear in what dimension they claim that we are equals-Worth or Authority (or perhaps something else).
\end{abstract}

Keywords Basic equality · Equal Worth · Equal Authority · Perfectionism · Political liberalism $\cdot$ Social contract

Nikolas Kirby

nikolas.kirby@bsg.ox.ac.uk

1 Blavatnik School of Government, Oxford, UK 


\section{Introduction}

'That all human beings are one another's equals' is often taken to be our shared starting point - the first article of constitutions; the indignant riposte of the oppressed; the cry of revolutionaries; the bland motherhood of politicians- the common basic premise of all contemporary political thought. ${ }^{1}$

This claim of 'basic equality' amongst human beings is supposed to be distinct from two other claims. First, it is intended to be distinct from the much more controversial claim of distributional equality. Our basic equality denotes some natural, inalienable property that we have to the same degree. Distributional equality, by contrast, is the further claim that, in virtue of such basic equality, we should be distributed equal shares of something, whether that be resources, opportunity, happiness or anything else. Basic equality, therefore, is something to be recognised and respected. Distributional equality is something to fail or succeed in achieving. ${ }^{2}$

Secondly, basic equality is also intended to be distinct from its own basis. Basic equality denotes a normative property, that is, the same level of some value, good or reason for action. The basis of basic equality, by contrast, is the non-normative property in virtue of which we have this normative property; whether it be our shared rational capacity, humanity, empathy, having been made in the image of God or whatever else. It is the metaphysical basis of our basic equality. However, we also expect it to play an epistemological role, that is, we expect to identify those who instantiate basic equality in this world by identifying who shares its basis. ${ }^{3}$

According to this picture, within contemporary political thought, therefore, we disagree bitterly about whether basic equality entails distributional equality, and if so what precisely is to be distributed. We also disagree about how to solve the difficult problem of what is the basis of our basic equality, if we believe it to be soluble at all. However, we all agree that all human beings are one another's equals. This agreement forges the unity of contemporary political thought. It is the shared egalitarian plateau from whence all other arguments begin. ${ }^{4}$

In this paper, I shall argue that this unity is false. Our political thought is, in fact, deeply divided between at least two very different concepts of basic equality. They

\footnotetext{
1 Pojman and Westmoreland (1997), 1: 'It is one of the basic tenets of almost all contemporary moral and political theories that all humans are essentially equal, of equal worth, and should have this ideal reflected in the economic, social, and political structures of society.' See also Wasserstrom (1971), 115; Dworkin (1977), 272-273; (1985), 191; (2000), 11; Kymlicka (2002), 4; Pojman (1992), 605; Scanlon (2004), 2; Dahl (2006), 4; Sen (2009), 291; Smith (2011), 1; Carter (2011), 540.

2 For the classic debate on distributional egalitarianism, see Dworkin (1981b), c), Arneson (1989), Cohen (1989), Sen (1992), Roemer (1996), Anderson (1999).

3 For key papers on the basis of basic equality, see Spiegelberg (1944), Berlin (1956), Bedau (1967), Benn (1967), Rawls (1971), 504-512, Williams (1973), Llyod Thomas (1979), Vlastos (1984), Arneson (1998), Waldron (2008), Carter (2011). It is true that some of these authors do not draw this tripartite structure. Instead, they only describe two elements: distributional equality as a prescription that applies to a set of individuals, and the 'basic equality' as the descriptive property in virtue of which one is a member of that set of individuals. Nothing I say here rejects this way of understanding basic equality, I just consider it to involve further alternative concepts, see n. 6 .
}

${ }^{4}$ Kymlicka (2002), 5. 
denote two very different meanings within the claim 'That all human beings are one another's equals'. And, whilst they are not in themselves logically inconsistent, they indicate two very different starting points for political thought. I shall call these concepts 'Equal Worth' and 'Equal Authority'. Differentiating these two concepts helps us clarify the original source of many of our disagreements, currently obscured by the false fancy that, in the end, at least we all start from the same one common fundamental premise. ${ }^{5}$

Finally, to draw upon the obvious inspiration for this paper, as Berlin discusses two concepts of liberty, I do not pretend that there are not more concepts of basic equality. Instead, merely, 'I propose to examine no more than two of these sensesbut those central ones, with a great deal of human history behind them, and, I dare say still to come. 6

\section{Equal Worth}

The first concept of basic equality I shall call Equal Worth: each individual's good is of equal moral significance. It is a concept variously expressed throughout political thought, not only as 'equal worth' itself, ' but also as 'equal consideration', 'matter[ing] equally', 8 'equal intrinsic weight', 'equal value', 'the equal primary importance of everyone's life', ${ }^{10}$ being worthy of 'equal concern' 11 and other formulations. ${ }^{12}$ However, since the idea of 'someone's individual good' itself is equivocal, Equal Worth is best understood as coming under two different conceptions.

One the one hand, there is the claim that all human beings - their bodies, minds and/or souls - are of equal value. ${ }^{13}$ This is to claim that we have the kind of value we might attribute to a precious artwork, or a natural environment, or a sacred ritual. We are valuable things to be cherished, nourished and respected. We have value in-

\footnotetext{
5 Whilst I cannot find any other author who has drawn this distinction nor its implications, it is prefigured in a few places. See, Amy Gutman's distinction between 'Equal Passions' and 'Equal Rationality' (Gutmann 1980, ch. 1), although this distinction appears to substitute the question of the basis of basic equality and the concept of basic equality itself; and, Ian Carter's distinction between basic equality regulating relations between individuals, and that regulating relations between the state and the individual (Carter 2013).

${ }^{6}$ Berlin (1969), 121.

7 Pojman (1997); Vlastos (1984), 43ff; Dahl (2006), 4. It is often also the assumption of its opponents: Kekes (1990), 106ff.

8 Kymlicka (2002), 3-4.

9 Haksar (2003), 96; Haksar (1979), 17.

10 Nagel (1991), 131.

11 Dworkin (2000), 128. See also, 'In Defense of Equality' (1983), 24.

12 For example, Jeremy Waldron who states that to claim that 'all humans are equals' is to claim that: ' $[\mathrm{M}]$ oral argument (including arguments purporting to justify discrimination) ranges over the good of all human beings, without any fundamental division or differentiation' Waldron (2008), 9. See also, Benn (1967), 62; Lukes (1977), 98; Hurka (1993), 161; Pettit (2012), 78-79.

13 I attribute this conception to Pojman (1997); Kekes (1990), 106ff.
} 
and-of-ourselves, and that value is not for the sake of anyone else, not even ourselves. If it is for anyone, it is for God alone.

On the other hand, there is the claim that the fundamental good for each human being-our utility, happiness, welfare, interests or some other cognate-is of equal weight. ${ }^{14}$ This is to claim that in the ultimate moral calculus, when tasked with promoting the good in general, promoting the good for each individual is of equal moral significance. Equal weight, therefore, is a function that maps the value of things for any individual (their individual good) to that which is valuable in-and-ofitself (the good in general).

The conception of Equal Worth qua equal value stretches back at least as far as early Christian thought. ${ }^{15}$ Being made in the image of God, we are all, equally, sacred objects. ${ }^{16}$ Our souls are of equal value, but not for our own sake. They are of value either in themselves or, if for anyone, for God. This value persists, no matter what the contingencies of life. Further, as a corollary of our value, our actions are of equal significance. Our actions, both good and bad, are to be judged on the same cosmic scales.

In part, this picture is a call to human action; to proselytise and save every human soul for the sake of redemption; to promote good actions, and diminish the bad for the sake of God. However, it also an excuse for inaction. For if every soul has equal value, regardless of the vagaries of human existence, and if the actions of each soul are to be weighed equally no matter their position, then so long as actions performed under more difficult circumstances are valued more highly than those made under easy circumstances, God's cosmic scales provide all the moral balance required in this life and the next. So long as it is harder for a rich man to enter into Heaven than for a camel to pass through the eye of a needle, ${ }^{17}$ we can leave distributional justice to God.

This picture is also consistent with a world in which each person has her place. Our souls have equal value, but their purpose is to serve God in different ways, whether as a peasant, merchant, priest or king. This impersonal organic system is easily at hand when our own (equal) value, is not for ourselves, but for God. ${ }^{18}$ So it is coherent that our individual value for God is only realised via our individual value as a part of a society.

\footnotetext{
${ }^{14}$ I attribute this conception to Waldron (2008), Kymlicka (2002), Dworkin (1983, 2000), Arneson (1998), Nagel (1991), Haksar (2003), Vlastos (1984), Benn (1967), Lukes (1977), Hurka (1993), Pettit (2012).

15 '[I]t was only the Church which enriched mankind with this state of distress!- "Equality of souls before God", this falsehood, this pretext for the rancune of all base-minded, this explosive concept which finally became revolution, modern idea and the principle decline of the entire social order-is Christian dynamite.' Nietzsche (1968), ch. 62, 186. Goodman (1976) argues that the doctrine is foreshadowed in the Old Testament, for example, Malachi 2:10. See also, Morgan (1943), 115; Spiegelberg (1944), 101; Pojman (1991), 496. For a contrasting position, where theology grounds inequality as Unequal Value one might look at the Mahabharata, where individuals are born into the world as unequals because of differences in their purity or evil, picked upon in previous lives. See, Somjee (1967), 187.

16 Genesis 1:27.

17 Matthew 19:24.

${ }^{18}$ Hence the Platonic system was so easily co-opted by the Neo-Platonists of the Middle Ages. See, Sigmund (1967), 135-137.
} 
What is not central to this whole picture, however, is our own individual good, that is, what is valuable for our own sake. Our soul's value, and that of our actions, is for the sake of God, and perhaps intermediately for our society. Our own individual good is unnecessary for this picture, and perhaps this is why, its earthly form is so easily reducible to non-normative desires, pleasures and passions, that can be cast as valueless, animalistic temptations; mere obstacles to serving the greater good of God. ${ }^{19}$ All that is left of what is genuinely valuable for our own sake, then, is our own individual good after life. Conveniently, this postdeath individual good plays a supporting role, reinforcing the rest of the organic system. It only arises as a reward for realising the greater good of God, in the form of redemption in Heaven. It follows that whilst the equal weight of our individual good is consistent with this system, and a natural corollary of equal value, it is relegated along with our individual good to a peripheral, supporting role.

The death of God precipitates the collapse of this system. ${ }^{20}$ Once the service of God ceases to define the good in general, our own individual good makes a move to the heart of our modern moral picture. As humanism reaches its apotheosis in utilitarianism, the good in general becomes entirely defined as a promotion of people's individual good. And as this shift occurs, so does equal weight replace equal value as the central sense in which we have Equal Worth.

In this utilitarian picture, equal value entirely disappears since only what is valuable for our own sake constitutes the good in general. However, equal weight becomes indispensable. As Mill states, 'That principle [the utilitarian maxim] is a mere form of words without rational significance, unless one person's happiness supposed equal in degree (with the proper allowance made for kind), is counted exactly as much as another's'. ${ }^{21}$ Thus, 'each to count for one, nobody for more than one. ${ }^{22}$ Or as more expressly stated by Bentham: 'the happiness of the most helpless pauper constitutes as large a portion of the universal happiness as that of the most opulent members of the community'. 23

With this new fundamental status, equal weight also becomes the object of sustained attack by the forerunners and contemporaries of classical utilitarianism. Keeping all the other key premises of utilitarianism intact, these thinkers reject equal in favour of unequal weight. The world is full of unequals of Unequal Worth,

\footnotetext{
19 As Morgan (1943), 115, suggests the equal value of our soul in the eyes of God may well be modernistic gloss for 'Equally sinful'. See also, Ruskin (2007), vol. II, 159, [ch IV, §x]. Rosen remarks on this equivocation in Christian thought: Rosen (2012), 14.

20 Nietzsche (1974), s 125.

21 Mill (1910), 58.

22 As Waldron notes, it is 'surprisingly difficult to find a source for the Benthamite slogan'; it is really only known by its quotation by Mill (1910), 58: Waldron (2008) 10, fn 26.

23 Bentham (1983), 107. For its usage in contemporary utilitarian thought see: Hare (1981), 26, who casts the fundamental principle as 'giving equal weight to the equal interests of all the parties'; Harsanyi (1982), 47: similarly states that utilitarianism seeks to 'always assign the same weight to all individuals' interests'. See also, Dworkin (1981a), 201, and Sen (1992), 14.
} 
depending upon their 'dignity or moral importance', their 'race', or 'higher or lower capacities'. 24

However, the history of political thought bears out the result. And, whilst we may still utilise the concept of Unequal Worth as unequal weight to describe the fundamental difference between us and other lesser animals, ${ }^{25}$ there appears to be an almost global assumption that we all have Equal Worth in the sense of equal weight.

There is still conceptual space within this dominant current system for equal value. However, it now takes on the peripheral role. It may be cast as the source or consequence of the equal weight of our individual good, but either way it is not the operational focus. The aim of this moral system, and its political extensions, is some promotion and distribution of individual good. And regardless of whether this is a utilitarian, egalitarian, sufficientarian, prioritarian or whatever else distribution, the individual good of each person is to be accorded equal weight. ${ }^{26}$

\section{Equal Authority}

Equal value and equal weight are different. However, I cast them loosely as two different conceptions of the one concept because of their close relationship. They are both claims about the nature of the good, and our place within it. One is easily cast as the corollary of the other. And so long as moral and political philosophy is concerned with the promotion and distribution of the good, whatever it is, Equal Worth under some conception is bound to play a foundational role.

However, to borrow Berlin's opening line, 'If men never disagreed about the ends of life, if our ancestors had remained undisturbed in the Garden of Eden, the studies to which the Chichele Chair of Social and Political Theory is dedicated

\footnotetext{
24 'In comparing the moral qualities of actions ... we are led by our moral sense of virtue to judge thus; that in equal degrees of happiness, expected to proceed from the action, the virtue is in proportion to the number of persons to whom the happiness shall extend (and here the dignity, or moral importance of persons, may compensate numbers)' Hutcheson (1725), 283-284; individuals, or races, with higher capacities (i.e. capacities for a higher sort of well-being) have a right to more than merely equal consideration as compared to those of lower capacities. Hence the formula, 'Everyone to count for one, nobody for more than one', must be interpreted to mean 'everyone's good to count for as much as the like good of any one else.' Rashdall (1924), 238.

25 See, Waldron (2008), 9; Haksar (1979), 65-66; contra Singer (1977), 22.

26 It might be pressed at this point, that upon closer inspection prioritarianism must, by definition, reject basic equality as equal value. This is because, 'Prioritarianism holds that the moral value of achieving a benefit for an individual (or avoiding a loss) is greater ... the lower the person's level of well-being over the course of her life apart from receipt of this benefit. Arneson (2013) [Emphasis added]. Parfit (1997), 'The Priority View: [is defined as] Benefiting people matters more the worse off these people are', 213.

Accordingly, given two individuals with different absolute levels of individual good, on the priority view, one extra 'unit' of individual good arising in the individual with less total individual good is more morally valuable than one extra 'unit' arising in the individual with more total individual good. (See, a similar point made regarding minimax theories, Hurka (1993), 161.) There is, however, no need to take this 'per unit' view to be the best interpretation of what it means to hold that the 'individual good of each individual is of equal value'. A better interpretation might simply be that the total individual good of any individual is as morally valuable as the same total individual good in any other. This, arguably, was Mill's understanding of basic equality: 'It may be more correctly described as supposing that equal amounts of happiness are equally desirable, whether felt by the same or by different persons.' Mill (1910), 58.
} 
could scarcely have been conceived. ${ }^{27}$ Much political philosophy is concerned, first and foremost, not with the promotion and distribution of the good, but with our disagreement about it. With such disagreement arises questions of authorityepistemic and practical; and hence, a different domain for basic equality.

We all have different epistemic capacities including, it would seem, in the domain of the normative. Some know better than others what we should do and why. For much of human history, this unequal epistemic authority has been thought to justify a form of basic inequality: unequal practical authority.

For Plato and Aristotle, it was obvious that those who knew best the ends of life were unequals to the rest. ${ }^{28}$ They were vested with fundamental authority over others. By authority, I mean practical, de jure authority, that is, 'the right to rule'. Such a right can be understood, using contemporary terminology, as the ability to create a decisive reason for an individual to act by determining that she should so act. ${ }^{29}$ By 'fundamental', I mean that such authority is not derived from some previous exercise of authority between the relevant individuals. It is not the product of delegation, or abdication, authorisation, agency or consent.

Whilst putative relations of epistemic superiority and inferiority have often been taken to ground such basic inequality as Unequal Authority between individuals, the history of political thought bears out a range of other bases too-sometimes as loose proxies for epistemic authority, ${ }^{30}$ other times tracing persons' roles in God's inexplicable organic system, other times thinly covering bald assertions of power. In this way, Unequal Authority has been grounded by differences in race, sex, class, education, ${ }^{31}$ property, age, 'virtues and talents', ${ }^{32}$ and patrilineality, ${ }^{33}$ to name a few.

In some societies, these bases ground great chains of being, a natural hierarchy from God, down the archangels and angels, through kings and bishops, the other classes to the lowliest peasant, and sometimes beyond. ${ }^{34}$ Here fundamental authority is exhaustive and transitive all the way down. In other societies, however, the multiplicity of bases ground a confusing system, which threatens to be inconsistent and incoherent. The fundamental authority of an upper-class, rich,

\footnotetext{
27 Berlin (1969), 'Two Concepts of Liberty'.

${ }^{28}$ Plato (1892), 56ff [II, 375ff]; Aristotle (1976), 174 [1131a20-1].

29 Broadly speaking I am willing to accept Joseph Raz's analysis of how such reason comes to be decisive, that is, by being the systematic combination of two reasons. First, a reason to act as directed; and secondly, an 'exclusionary' reason, not to act on the basis of otherwise valid reasons to act to the contrary (Raz (1975); repr., (1999), 39-84; 189-191; Green (2010), 225; Raz (2010), 282; 290-291). In this way, the reason created by the command is not added and weighed against other reasons, but simply overrides them. Raz calls such reasons, 'protected' or 'pre-emptive' (Raz 1986, 59).

${ }^{30}$ Eg., Locke's somewhat ad hoc justification for a husband's authority over his wife: Locke (2003), 135.

${ }^{31}$ Eg., Mill's On Representative Government, ch. VIII, in Mill (1910).

${ }^{32}$ Eg., Thomas Jefferson argued for a 'natural aristocracy' based upon 'virtues and talents'. He supported democracy, therefore, not as a form of equal fundamental authority (see below) but as the most effective instrument to identify the natural aristocracy. See, 'Jefferson to Adams 28 Oct. 1813' in Cappon (1959), 2:387-392. See also, Santayana (1905), 109ff.

${ }^{33}$ Eg., Filmer (1685).

34 Lovejoy (1953).
} 
uneducated, white male relative to all others may be easy to define; but perhaps not so an upper-class, poor, educated, black female. The proper distribution of fundamental authority is a difficult task in this society, best left to the finest theological, legal and philosophical minds of their generation.

It is within such hierarchical societies, however, that a different concept of Basic Equality is forged. Whilst these societies as a whole define sets of unequals, they also define sub-sets of equals. These are individuals of the 'same species and rank' ${ }^{35}$ Individuals who may, respectively have superiors or inferiors, yet with respect to one another have equal fundamental authority. Basic Equality as Equal Authority, therefore, is a concept most easily first grasped from within the framework of an unequal society. Once understood, however, the radical move is, even gradually, to extend its predication to the entire set of moral agents.

Like Equal Worth, the claim that all individuals are equals in this sense of having Equal Authority has a multitude of different expressions (equal authority, power, sovereignty, dignity, command, right, dominion, jurisdiction) ${ }^{36}$ that can be grouped under two different conceptions.

On the one hand, there is the claim that all individuals have equal fundamental authority over all. We might dub this the 'democratic conception'. Under this conception, all individuals have an equal right to determine the laws that will apply to all, including themselves; and this right is realised via some procedure-direct voting, participatory fora, representative elections, majority ballot, and/or consensus decision making.

On the other hand, there is the claim that each individual has fundamental authority over herself and only herself. We might call this the 'liberal conception'. This conception has two components. First, it has a negative clause: no individual has fundamental authority over any other individual. No one is anyone else's master, no one is anyone else's subject. Secondly, it has a positive clause: each individual has fundamental authority over herself. Each individual is both her own master and her own subject. It follows that the 'liberal conception' of Equal Authority, also implies a parallel concept of 'basic freedom' also composed of two clauses, that is, first, a freedom from the fundamental authority of anyone else; and, secondly, a freedom to exercise fundamental authority over oneself. ${ }^{37}$ Hence, the common, often unanalysed, dyad 'all humans are free and equal. ${ }^{38}$

Fundamental authority 'over oneself' may at first appear to be a somewhat contorted extension of the concept of authority. ${ }^{39}$ However, in this context, it means nothing more than one having ability to give oneself a decisive reason to act by

\footnotetext{
35 Locke (2003), II.II.4.

36 John Liliburne names virtually all of them in his claim that: 'All and every particular and individual man and woman ... are and were, by nature all equal and alike in power, dignity, authority, and majesty, none of them having by nature any authority, dominion, or magisterial power one over or above another' Lilburne (1938), 317-318.

37 Freedom from authority is somewhat surprisingly absent from discussions of the various concepts and conceptions of liberty, presumably because it involves the absence of normative interference rather than physical interference. See, Berlin, (1969), 'Two Concepts of Liberty'.

38 See, Macedo (1990), 36-37; Waldron (1993); Quong (2010), 2-3.

39 See, Raz (1979), 18.
} 
determining that one so should act. The most obvious examples include promises and contracts. However, I also take it to include a principle of conscience, that is, where one gives oneself a new decisive reason to act upon one's own conviction by coming to believe in that conviction, even if the independent grounds for that conviction ultimately turn out to be false. ${ }^{40}$

The democratic conception of Equal Authority emerges with democracy itself, amongst the small city-state republics of Greece, only to largely disappear until the emergence of the similar small city-state republics of the Renaissance. ${ }^{41}$ This is perhaps no great coincidence, since the democratic conception ultimately does more to legitimise the fundamental authority of the community, rather than that of the individual. This is because, whilst each individual is indeed an equal with the same right to rule over all others, that right is impotent when compared with the aggregate right of all others. Quiet rightly, the democratic conception allows each individual to conceive of themselves as equal members, as equal citizens of their communities. However, that membership is primarily as a subject rather than as a ruler.

For this reason, the so-called 'Liberty of the Ancients' is a misrepresentation. ${ }^{42}$ There is no great freedom ensured by the democratic conception. At best one is free from the superior fundamental authority of any other individual. However, this is easily replaced by the tyranny of the majority. The democratic conception only entails 'self-governance', therefore, if the self is identified with the community as a whole. $^{43}$

It is for this reason that the democratic conception comes under great pressure as the community grows and diversifies. ${ }^{44}$ The mental gymnastics required to convince oneself that one is governing oneself, by being governed by the majority become harder as one is less likely to have anything in common with the majority. In particular, as society grows to include a multiplicity of different conceptions of the good, one can no longer identify a common set of values that could define the communal self. Competing epistemic authorities begin to undermine the democratic conception of equal practical authority.

The liberal conception, by contrast, emerges from the internal fracturing of the powers - spiritual and temporal — that held together the larger kingdoms and empires from the Middle Ages well into the Renaissance. Up until this point, the Catholic Church retained supreme and unquestioned epistemic authority, and in turn verified that God had willed the unequal fundamental practical authority of the monarchical regimes. ${ }^{45}$

\footnotetext{
${ }^{40}$ See, Gaus (2015), 136-156.

41 Although note the many other origins of democracy in Africa, amongst the Vikings, and other souces: Isakhan and Stockwell (2011).

42 Constant (1988), 323.

43 See, Sabine (1937), 30; Mill (1910), 67-68.

44 Wollheim (1962), 72.

45 As David Held states, the 'Christian world-view transformed the rationale of political action from that of the polis to a theological framework', such that the notion of 'good' lay in submission to God's will. Thus, 'how the will of God was to be interpreted and articulated with systems of secular power preoccupied Christian Europe for centuries, until the very notion of single religious truth was shattered by the Reformation.' Held (1996), 37.
} 
Yet, 'things fall apart'. ${ }^{46}$ The Great Schism cleaved the Church in two. The remaining Western, Catholic Church continuously tussled for power with the very Holy Roman Empire that it had anointed. The Reformation split what remained of the Catholic Church's authority into competing Protestant sects, many of whom did not even claim epistemic authority for their own clergy, but instead placed their congregation in direct communion with God. The English gentry precipitated the Civil War as they aimed to assert the authority of Parliament over Charles I.

These crises reshaped the relationship between contemporary epistemic and practical authority structures. Where previously one could presume a shared belief in who knew best the will of God (the Church), and thus who knew who God had willed to govern (the Monarch); now, one could not presume such a shared belief. Some saw, in this new situation, the operation of defective reasoning by those who disagreed. They had somehow been corrupted. This justified war, oppression and even the establishment of new isolated societies to purify and restore homogeneity of belief. $^{47}$

Others, however, made a novel conceptual move. They realised that God himself must have given all human beings their reasoning capacity, and expected them to act upon it. If this was God's will, then the starting point of any holy action was to follow one's own reasoned beliefs. One's God-given capacity to be one's own epistemic authority thus grounded one's own fundamental practical authority over oneself, and oneself alone. And, since all individuals had this capacity, all individuals must be equals in having such fundamental authority: 'Every man by nature being a king, priest prophet, in his own natural circuit and compass, whereof no second may partake but by deputation, commission, and free consent from him whose right it is. 48

Given this new liberal conception of Equal Authority, the authority of the state could still be justified but only derivatively. It must derive from the fundamental authority of all individuals, exercised via their consent, authorisation, agreement or social contract. As the fifteenth century cardinal, Nicholas of Cusa stated, when advocating reform of the Holy Roman Empire:

For if by nature men are equally powerful and equally free, the valid and ordained authority of one man naturally equal in power with the others cannot be established except by the choice and consent of the others, even as law also is established by consent. ${ }^{49}$

This liberal conception of Equal Authority can be traced most prominently through all the key figures of social contract theory. ${ }^{50}$ It is the foundation of Hobbes's claim that only by our own consent and authorisation can we come under

\footnotetext{
46 Achebe (2006), citing W. B. Yeats, 'The Second Coming' in Yeats (1992).

47 After all, this is the original aim of those pilgrims going to Northern Ireland and America.

48 The Leveller, Richard Overton in his 'An Arrow Against All Tyrants' cited in Woodhouse (1951); Nozick (1974). For other Leveller references to Equal Authority cited in Woodhouse's collection see John Lilburne at 317 and Richard Rain borough at 53.

49 Nicholas of Cusa (1954), II.14.

${ }^{50}$ It also runs through anarchist thought, eg. Wolff (1970).
} 
any duty to obey the sovereign, even if he does not explicitly articulate it as a concept of basic equality. ${ }^{51}$ It is the most important part of Pufendorf's heterogeneous concept of basic equality. ${ }^{52}$ It emerges fully recognised as the basic meaning of the claim 'that all human beings are equal' in Locke:

'That all men by nature are equal,' I cannot be supposed to understand all sorts of equality ... [instead, I mean] the equality which all men are in, in respect of jurisdiction or dominion one over another; which was the equality I there spoke of, as the proper business in hand, being that equal right every man hath to his natural freedom, without being subject to the will or authority of any other man. ${ }^{53}$

Unlike the value and weight conceptions of Equal Worth, the liberal and democratic conceptions of Equal Authority are incompatible. This is because they both make incompatible claims about the distribution of fundamental authority within a society. Both cannot be true. However, one can ground the other, if the latter becomes a claim about the distribution of derivative not fundamental authority. And this is precisely what begins with Locke. ${ }^{54}$ The Lockean social contract based upon the liberal conception grounds the derivative (proto-)democratic authority of Parliament.

In this way, for the first time, we get the logical space for liberal, democratic constitutionalism. The democratic conception as a theory of fundamental authority is actually antithetical to a constitution that purports to limit the ongoing fundamental authority of the citizens to rule by majority over themselves on any matter, particularly insofar as it seeks to protect individual and minority rights. ${ }^{55}$ After all, what greater authority can a constitution have over the combined fundamental authority of the majority?

However, starting one's theory with the liberal conception instead, a constitution can be secured with more fundamental legitimacy over and above the even more derivative standing of the democratic system, since the latter is only grounded by the former.

This (albeit unequal) marrying of the liberal and democratic conceptions reaches its pinnacle in Rousseau. Each individual exercises her fundamental authority over

\footnotetext{
${ }^{51}$ Hobbes (1962), 176. Whilst Hobbes grounds his social contract on the basic proposition and thus the equal authority it contains, strictly speaking, it is not what he means when he calls human beings 'equals'. Instead, he denotes their physical capacities: 'Nature hath made men so equal, in the faculties of the body and mind'. This is to define basic equality by reference to the basis of equal authority, rather than equal authority itself.

52 Pufendorf (1994), III.2.8: '[T]he actual establishment of sovereignty requires some antecedent human deed, and a natural ability to rule by no means gives anyone sovereignty over those whom nature has given a character fit for servitude. Nor does the fact that something is useful to another immediately allow me to impose it on him by force. For men enjoy natural freedom to an equal degree, and they cannot allow it to be diminished without their express, tacit, or interpretive consent, or without some other deed of theirs by which others have acquired a right to seize it from them even against their will.'

${ }^{53}$ Locke (2003), 54. See, Rousseau (2004), I.2.1; I.2.2-3; I. 9.8. And, Kant (1996), 4:432; Kant (1996), 6:238.

${ }^{54}$ For the view that modern democratic theory begins with Locke not Rousseau, see Shapiro (2002), 309.

55 Note, Waldron (1999), ch. 11.
} 
herself to authorise the virtually absolute derivative authority of all individuals over all, in the form of majoritarian direct democracy. Further, by grounding such a classical vision of small city-state republican democracy on liberal foundations, Rousseau can also reincorporate the classical identification with 'community' into liberal, democratic constitutionalism.

This achievement, however, is obfuscated by Rousseau's seemingly paradoxical claims that by being an equal member within such a state whereby everyone rules over everyone, one continues to be ruled only by oneself. ${ }^{56}$ One can, therefore, be 'forced to be free'. 57 These claims trade precision for rhetorical flourish, equivocating between instances of fundamental and derivative authority. The clearer, less pseudo-metaphysical claim is that within Rousseau's state, every individual is: free of the fundamental authority of any other; and, rules over oneself by exercising one's fundamental authority over oneself to ground the derivative authority of the democratic decision making body. Thus, when this body consequently rules derivatively over everyone, one continues to be ruled fundamentally by oneself. And, when it enforces its rules against an individual, it only forces that individual to obey the implications of her own previous exercise of fundamental authority over herself.

Finally, with Kant, the role of the liberal conception expands beyond politics, to ground all moral obligation:

If we look back upon all previous efforts that have ever been made to discover the principle of morality, we need not wonder now why all of them had to fail. It was seen that the human being is bound to laws by his duty, but it never occurred to them that he is subject only to laws given by himself but still universal and that he is bound only to act in conformity with his own will, which, however, in accordance with nature's end is a will giving universal law. $^{58}$

Of course, Kant does go on to state that the 'lawgiving itself, which determines all worth must for that very reason have a dignity [würde], that is, an uncondition, incomparable worth [Werth]. ${ }^{59}$ He then notes that the 'dignity' of each human being is, properly speaking, merely the dignity of this self-lawgiving capacity. Kant,

\footnotetext{
${ }^{56}$ Rousseau (2004), I.6.4: 'A form of association which will defend the person and goods of each member with the collective force of all, and under which each individual, while uniting himself with the others, obeys no one but himself, and remains as free as before.' See also. Rousseau (2004), II.4.9.

57 Rousseau (2004), I.7.8.

58 Kant (1996), 4:432. An explicit statement of basic equality as equal authority follows in Kant's Doctrine of Right, whereby we all have 'innate equality, that is, independence from being bound by others no more than one can in turn bind them; hence a human being's quality of being his own master (sui juris). Kant (1996), 6:238.

59 'For, nothing can have a worth other than that which the law determines for it. But the lawgiving itself, which determines all worth, must for that very reason have a dignity, that is, an unconditional, incomparable worth; and the word respect alone provides a becoming expression for the estimate of it that a rational being must give. Autonomy is therefore the ground of the dignity of human nature and of every rational nature': Kant (1996), 4:436. Anderson (1999), 312 similarly refers to 'Equal Worth; in a way that is consistent with it being Equal Authority. She is also explicitly following Rawls (1980) who himself is obviously following Kant.
} 
therefore, is often taken to hold something akin to an Equal Worth concept, rather than Equal Authority. There are a number of complications regarding the proper translation of 'würde'. However, we can put these aside. This is because, no matter its meaning, if we follow Kant closely, each person's authority over herself grounds her würde; not vice versa. Kant argues for the proposition that one has authority over oneself without any reference to würde, (or Werth or any possible claim about the nature of the good). Further, once such authority is established, by definition, its exercise gives one a decisive reason to follow the laws one gives oneself, and excludes the authority of others. No reference to würde is required to establish this. The fact that this capacity also happens, putatively, to have würde (whatever its precise meaning) is just supervenient. It plays no role in justifying either one's authority over oneself or the binding quality of the duties it can create. In this way, Equal Authority remains Kant's most basic equality, even if he takes that basic equality to ground a further, supervening and derivative 'equality of würde'.

\section{Basic Equalities in Contemporary Political Thought}

The history of political philosophy offers up these two concepts of Basic EqualityEqual Worth and Equal Authority (and their various conceptions) - to contemporary thought. They are central to it.

On the one hand, we have a broad church of so-called 'perfectionist' or 'comprehensive' theories. ${ }^{60}$ All these theories, share the common claim that political philosophy must begin with a conception of the good. We must make some claim about the true ends of life. The state is, then, but a machine to achieve these ends. And, its authority depends upon whether it is best able to 'service' those ends. ${ }^{61}$ Most importantly, the state does not require the consent, implicit or otherwise, of its subjects to have authority. Instead, that authority is fundamental and arises because of the moral fact that individuals will best conform with their true reasons for action by obeying it, rather than if they attempted to act on their own. Central to this picture, therefore, is Basic Equality as Equal Worth under either conception, but most prominently in the form of equal weight. As Ronald Dworkin claims, there is a unity in their 'abstract egalitarian principle', that is, 'government must act to make the lives of those it governs better lives, and it must show equal

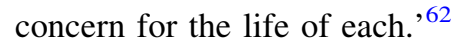

On the other hand, there are the heirs of social contract theory: the political liberals; the advocates of public reason; the purveyors of deliberative democracy (as

\footnotetext{
${ }^{60}$ In this category, for example, I place: Raz (1986), Hurka (1993), Wall (1998), Arneson (2000), Haksar (2003), Enoch (2012), and, I think a rather confused Dworkin (1983, 2000). See, Quong (2011) for the distinction between perfectionist and comprehensive theories.

61 Raz (1986, 2006).

62 Dworkin (2000), 128. [Emphasis added]. 'In Defense of Equality', (1983), 24: Dworkin also states: 'I begin by setting out what I shall call the abstract egalitarian thesis. From the standpoint of politics, the interests of the members of the community matter, and matter equally.'
} 
well as the philosophical anarchists and the rights-based libertarians). ${ }^{63}$ For these philosophers, moral philosophising may begin with each individual's attempt to work out the true ends of life. However, political philosophy as an account of legitimate authority and coercion only begins when we address the fact that these individuals' attempts will inevitably precipitate disagreement and conflict. Political philosophy, therefore, must begin with a prior theory of fundamental authority defined independent of any conception of the good, to adjudicate upon what to do given our disagreement about the good. For these philosophers, generally the liberal conception of Equal Authority is that prior theory of fundamental authority. As the most recent prominent Rawlsian acolyte states: 'We correctly think of ourselves as free and equal from the moral point of view. We all have the same moral status as free persons - as people who are not naturally under the authority of someone else. ${ }^{64}$

In this way, the two concepts of Basic Equality mark a well-known fundamental divide in contemporary political thought. In a way this seems obvious, but in fact it has been far from obvious to those who have written on the topic of Basic Equality itself. These philosophers have all tended to reach for a false unity. Most, in doing so, have put forward Equal Worth as the concept common to all contemporary political theories. ${ }^{65}$ The implicit assumption, it seems, being that those who advocate Equal Authority must ultimately hold it to be grounded upon our Equal Worth; the latter being logically prior to and justifying the former. However, this picture simply flies in the face of the actual arguments that Hobbes, Pufendorf, Locke and Kant make. None of these philosophers ever argue that our Equal Worth, or anything like it, grounds our Equal Authority. This is despite the fact that the former concept, in a Christianised form, was always a part of contemporary thinking, and thus readily available for use as a premise. Instead, for Hobbes, Pufendorf and Locke our Equal Authority arises as a function of God's will: how he made the world, whether we like it or not. And, for Kant it arises because of the transcendental metaphysics of reason itself. Equal Worth does not come into it (or, if anything, it comes as a consequence, as discussed above in Kant).

Today's political liberals have no recourse to theology or transcendental metaphysics to justify Equal Authority. Instead, they attempt to make epistemic arguments. Or, they invent new sui generis 'second personal reasons'. Or, they verge upon relativism. Or, they take it to be an unquestionable premise of contemporary culture. Or, they obviate between defeatist quietism and unhelpful bald assertion. Clearly, the task is hard. ${ }^{66}$ However, they continue to pursue this

\footnotetext{
63 In this category, for example Rawls (1993), Larmore (2008), Nussbaum (2011), Quong (2011), I think a rather confused Nagel (1987, 1991), Cohen (2009). On anarchism, see Buchanan (1978), 33; and for rights-based libertarians, see Nozick (1974), and Steiner (1994).

64 Quong (2010), 3. See also, Estlund (2008), 120: 'Another thing that is often meant by natural freedom is that no person is born under the authority of anyone else. The authority of one person over another is, as I have said, simply the moral power to require action. So this thesis of natural freedom is the claim that no one is naturally subject to another's commands in this way. The claim is not that there are no authority relations at all, but only that none are owed to nature.'

65 See above, n. 1.

66 However, not clearly harder than justifying the basis of Equal Worth, see Waldron (2008) and Carter (2011).
} 
task, because they are purposefully avoiding making the claim that our equal authority is justified because of our (equal) value as autonomous beings or the (equal) weight of the value of autonomy for us. Such a justification is precisely the kind of 'comprehensive liberalism' that political liberals explicitly reject. ${ }^{67}$ Political liberals aim to avoid relying upon any premise about the nature of the good to justify their theories, and thus a fortiori they avoid relying upon Equal Worth.

Political liberals, therefore, make no claim that our fundamental authority over ourselves is necessarily good for us, or makes us good individuals. If anything it is a cross to bear, a responsibility of being rational human beings with fallible conceptions of the good. We may well live worse lives than if we were under the supreme authority of an all-knowing, benevolent figure. However, our fundamental authority remains as a constraining fact, for better or for worse.

Whilst political liberals must hold that Equal Authority is the most basic sense in which we are equals, nothing about their position demands that they must reject Equal Worth as false. They can accept the truth of Equal Worth, as much as any other component of a true theory of individual good. However, just as with any theory of the good in general, the truth of Equal Worth in particular, can only be used to justify government authority on a basis that respects Equal Authority, not vice versa. Accordingly, it is only our agreement about the truth of Equal Worth that can make it a salient political principle, not its putative truth as a standalone fact. ${ }^{68}$

Political liberals, therefore, can quite comfortably assert the truth of both Equal Authority and Equal Worth (although the use of the latter in justifying political action is no longer 'basic'). Perfectionists, by contrast, struggle to achieve the inverse. If one seeks to ground one's politics in a theory of the good (including Equal Worth as a component), then one will only be able to justify Equal Authority if autonomy is the ultimate and insuperable individual good. However, this is generally taken to be implausible. ${ }^{69}$ As such, unlike the political liberals, the perfectionists are pressed into acknowledging that, in a (not basic but still important) sense all human beings are not equals. This is because some human beings have greater fundamental authority to direct the state and its citizens towards moral perfection than others. It is difficult for perfectionists, therefore, to prevent sliding into systems of Unequal Authority such as epistocracy.

Having said this, of course, political liberals are in the difficult position of dealing with citizens who will not consent to the social contract. These 'unreasonable' people risk being exiled outside the set of self-appointed equals. Each side, therefore, has their own cross to bear. My point is only that we should keep the distinction between those crosses clear, by keeping the difference between

\footnotetext{
${ }^{67}$ For a clear discussion of why autonomy does not ground political liberalism see, Nussbaum (2011).

${ }^{68}$ For this reason, it is not an argument against the basic-ness of the distinction between Equal Worth and Equal Authority that political liberals often expect governments to act on the basis of some elements of a conception of the good and application of the concept of Equal Worth to it (for example, assuming that in general living longer is better than dying earlier, or developing the doctrine of 'primary goods'). The point is that these considerations can be validly relied upon not because they are true, but because they are assumed to be so basic that every conception of the good will agree upon them.

69 Many, of course, believe that Kant makes this very mistake. This is understandable given the English translation. Wolff (1970), for example, follows this interpretation to his detriment.
} 
the two concepts of Basic Equality in mind. It is no use for a political liberal, for instance, to continue pointing out that perfectionists 'fail to treat people as equals', and to take that to be a knock-down argument. ${ }^{70}$ Perfectionists can simply agree with the political liberals that they do not treat people as equals in the Equal Authority sense, because it is necessary inter alia to distribute resources effectively in the Equal Worth sense. Instead, both perfectionists and political liberals need to begin by arguing for which concept of equality is truly basic.

\section{Other Putative Concepts}

At this point, one might be beginning to wonder whether Equal Worth and Equal Authority, whilst clearly different, may not be better understood as two conceptions of some higher concept, some tertium quid. If this were true, then despite the division between Equal Worth and Authority, we could still claim that there was a grand unity in political thought, some shared starting point upon which all our theories are built. As Dworkin and Kymlicka have hoped to claim, we are all offering interpretations of the same single concept of basic equality. Or at least, we are all constraining or judging our theories by the same moral implications drawn from the same basic concept. If this were true, then we would have a common framework within which to adjudicate between Equal Worth and Equal Authority.

However, all plausible, candidate, 'more basic' concepts fail. Their failures fall into three categories.

First, some putative concepts are too thin. In fact, some fail to offer any concept of equality at all. Thomas Scanlon, for example, suggests that basic equality means to 'count morally'. ${ }^{71}$ Or, as James Griffin states: 'respecting persons equally is looking at them from the moral point of view. ${ }^{72}$ However, this position simply confuses counting morally and being counting equally; being in moral view, and being equals in moral view. Animals, slaves, gods, monarchs may all fall into the former, but that certainly does not mean they all classify as the latter. ${ }^{73}$

Other concepts are also too thin because, whilst they offer a concept of equality, they remain incomplete predicates. They fail to define the key dimension which we are meant to be equals in. For example, take the concept of 'equal status'. 74 'Status' in its minimal sense simply means having a relative position in some dimension. So the claim that we all have 'equal status' simply means that we have equal relative positions in some dimension. However, this is about as substantial a claim as telling a blind person standing on the edge of the sidewalk that 'A traffic light is some colour'. Just as the blind person cannot even begin to determine the implications of

\footnotetext{
70 Eg., Nagel (1987), 223; Larmore (1996), 137; Nussbaum (2011), 44; Quong 96-107, 315.

71 Scanlon (2004), 2; Smith (2011), 6.

72 Griffin (1986), 163.

73 Formal equality conceptions are similarly too thin: see, Williams (1973), 230.

74 Stemplowska (2011), 355. Cupit (2000), 107. Cf., Sen (1992), 14. This same failing plagues ideas of 'equal standing' (Miller (2000) 231-232) and 'equal recognition' (Miller (2000), 231-232. See also, Scanlon (2003), 204-205; cited, Wolff (2012), 7; White (1997), 13-14).
} 
the status of the traffic light without knowing which light is on, we cannot begin to determine (interpret, argue, judge by, constrain with) the moral implications of the equal status of human beings without knowing which dimension they are equals in. ${ }^{75}$ Of course, one may understand 'equal status' to implicitly mean 'equal status in worth' or 'equal status in authority', or 'equals status in X other dimension'. However, in doing so one implicitly either has a concept of Equal Worth, or Equal Authority (or Equal X), but not a concept that includes all of them. ${ }^{76}$

Secondly, some concepts have the opposite problem: they are too thick. We grasp them by reference to a contextual set of claims about our interwoven rights and duties, or our abilities and values, which are present in our moral, political and legal practices. The concepts of 'equal dignity' and 'equal respect' are good examples. These concepts, however, are not basic at all. Instead, they encapsulate complex sets of implications that we might believe are entailed by our basic equality. For this reason, inevitably we gain any understanding of such concepts by analysing them as operations upon the actual basic concepts of Equal Authority or Equal Worth (or some combination of the two, see below). Kant is a perfect example. According to Kant, our Equal Authority is basic, but in turn it provides 'the ground of the dignity of human nature and of every rational nature. ${ }^{77}$ And equal respect, in turn, is simply defined as the set of implications that follow from the 'mere idea' of dignity. ${ }^{78}$ And in fact, when people dispute that Kant's concepts of dignity and respect are not grounded upon our Equal Authority, they argue instead that they are based on Equal Worth. ${ }^{79}$ Either way, equal dignity and respect remain downriver from whatever the actual source concept of basic equality is.

Finally, some concepts are composites: Vlastos' 'equal worth of the happiness and freedom of all human beings'; Dworkin's 'equal concern and respect'; and, Arneson's 'equal worth and dignity', are example. These composites, however, are clearly not themselves basic but instead are the combination of two putatively basic concepts. And, in most cases they are merely combinations of Equal Worth and Equal Authority, named under various synonyms, cognates, or 'thicker' derivative notions (Worth qua happiness, concern and worth; Authority qua freedom, respect and dignity). The problem with such composite concepts, therefore, is that they paper over the conflicts and inconsistencies between their more basic elements. As we argued above, the concepts of 'Equal Worth' and 'Equal Authority' cannot both

\footnotetext{
75 Further, there is no way in which we could think of the claim that we must all have equal status as somehow proven before and independently of the particular dimension in which we are equals. It would be like claiming that a fundamental proposition about a square is that they all are equals in some dimension. This is a true claim, but it only follows as an analytic corollary of the actual fundamental proposition which is that are all equals in the four sides that they have.

76 I fail to see how this is solved by Waldron's claim that we all have the same equal and high sortal status, that is, the same set of rights and duties once reserved for the highest beings in our societies. This still does not tell us in what dimension these beings were 'high' in the first place. See, Waldron (2011).

77 Kant (1996), 4:436. Otherwise put at 4:440, 'the dignity of humanity consists just in the capacity to give universal law, though with the condition of also being itself subject to this very lawgiving'.

78 Kant (1996), 4:439.

79 Eg., Rosen (2012).
} 
be truly basic to political thought, thus neither can the concept of 'Equal Worth and Authority'.

\section{The Implications}

But here we are met by the important question: Equals and unequals in what? This is a difficult problem, and entails philosophical speculation in the field of politics.

$$
\text { -Aristotle, Politics }{ }^{80}
$$

Berlin, somewhat artificially, welded his distinction between negative and positive liberty onto the great contemporary ideological battle of his day: between Western, democratic liberalism and Eastern, authoritarian communism. In this way, he drew implications for the real-life politics of his day. I make no such grand claim for the distinction between Equal Worth and Equal Authority. Undoubtedly, one might argue that it roughly tracks the divide between peoples and nations who manifest some form of great egalitarian, communal paternalism led by technocratic elites, and those who retain messy, seemingly sclerotic democratic systems held together (or held back) by mass politics. However, probably, more accurately the two concepts are constantly confused, misused and conflated in all political systems.

My more modest claim is that, in the beginning at least, the distinction between Equal Worth and Equal Authority has important implications for current debates within contemporary political theory itself. In short, my call to arms can be summed up in the demand that contemporary philosophers never again be allowed to claim 'that all human beings are equals' full stop. They must be clear in what dimension they claim that they are equals-Worth or Authority (or perhaps something else). This is because it is upon this particular dimension that any argument culminating or beginning with the proposition of basic equality will always turn. ${ }^{81}$

This will force philosophers to acknowledge whether they are relying upon either the premises of Equal Worth or Equal Authority. It will force them to realise that they may, without justification, be relying upon both at the same time. It will clarify when two theories can clash because they presume the same concept of basic equality, and when they are actually ships passing in the theoretical night. It will also make clear what concept of basic equality philosophers are seeking to ground in debates about the basis of basic equality. ${ }^{82}$ However, and most importantly, it will

\footnotetext{
80 Aristotle (1976), 86 [III 1282b].

81 Nor should they be excused the pseudo answers 'status', 'recognition', 'rights', 'respect', since they only beg the further questions 'status in what dimension', 'recognition of what property,' 'which rights', 'respect for what'. We cannot hope to complete the incomplete predicate of 'equal X', with simply further predicates that are incomplete themselves. For this very reason, quite rightly, one should ask of the answer 'Equal Authority' and 'Equal Worth', themselves, Equal Authority over what domain, ourselves alone or our community as a whole? And, Equal Worth of what type of good, our good merely in general, or what is good for our own sake? Only in this way, to clarify that someone is talking about the democratic conception or the liberal conception, the equal value conception or the equal weight conception.

${ }^{82}$ For a survey of the debate, Waldron (2008).
} 
enable us to account for, confront and, perhaps, overcome the 'Frustration' many philosophers face. As Enoch states:

I don't know of any other philosophical discussion that is quite like this: Talk to (broadly speaking) Rawlsians, and you are likely to get the impression that some kind of political liberalism, or a public reason account, is the only game in town. The only questions worth discussing, it seems, are within this framework, rather than about it. Theorists who reject this framework are often ignored, and the feeling one gets is that they just don't get it. Talk to many others, and you are likely to get the impression that Rawlsian public reason has been effectively refuted several times over, and indeed, that even this much was never necessary, as the theory was a non-starter to begin with. And the feeling one gets is that Rawlsians just don't get it, and that their tremendous influence in political philosophy is corrupting the field. ${ }^{83}$

This problem has arisen, in part, because of the conflation of the two concepts of Basic Equality. Both sides have, until now, believed that they were talking on the same terms, and thus could never understand why they could not comprehend one another. Now that these two concepts are separated we can see clearly where the most pressing debate in current political philosophy was Aristotles': what is the most basic concept of equality? Let us now, finally, set about answering this question.

Acknowledgements Many thanks to those who have read and critiqued drafts of this work, including Stuart White, Jeremy Waldron, Robert Mullins, Calum Miller and Thomas Sinclair. Thanks to audiences at Sciences Po, ECPR General Conference, Harvard University, University of Manchester and University of Pavia. Finally, thanks to the Rhodes Trust and the Department of Politics and International Relations, University of Oxford for their financial support.

Open Access This article is distributed under the terms of the Creative Commons Attribution 4.0 International License (http://creativecommons.org/licenses/by/4.0/), which permits unrestricted use, distribution, and reproduction in any medium, provided you give appropriate credit to the original author(s) and the source, provide a link to the Creative Commons license, and indicate if changes were made.

\section{References}

Achebe, C. 2006. Things fall apart. London: Penguin.

Anderson, E. 1999. What is the point of equality? Ethics 109: 287-337.

Aristotle. 1976. The ethics of Aristotle: The Nicomachean ethics. London: Penguin Books.

Arneson, R. 1989. Equality and equal opportunity for welfare. Philosophical Studies 56: 77-93.

Arneson, R. 1998. What, if anything, renders all humans morally equal? In Peter Singer and his critics, ed. D. Jamieson. Oxford: Blackwell.

Arneson, R. 2000. Perfectionism and politics. Ethics 111(1): 37-63.

Arneson, Richard. 2013. 'Egalitarianism'. In The Stanford encyclopedia of philosophy, Summer Edition, ed. Edward N. Zalta. http://plato.stanford.edu/archives/sum2013/entries/egalitarianism/.

${ }^{83}$ Enoch (2012). 
Bedau, H. A. 1967. Egalitarianism and the idea of equality. In Equality, ed. J. R. Pennock, and J. W. Chapman, 3-27. New York, NY: Atherton Press.

Benn, S. 1967. Egalitarianism and equal consideration of interests. In Equality, ed. J. R. Pennock, and J. W. Chapman, 61-78. New York, NY: Atherton Press.

Bentham, J. 1983. The works of Jeremy Bentham, eds. F. Rosen, and J. H. Burns, Oxford: Clarendon Press.

Berlin, I. 1956. Equality. Proceedings of the Aristotelian Society 56: 301-326.

Berlin, I. 1969. Four essays on liberty. Oxford: Oxford University Press.

Buchanan, J. M. 1978. A contractarian perspective on anarchy. In Anarchism: Nomos XIX, ed. J. R. Pennock, and J. W. Chapman, 43-62. New York, NY: New York University.

Cappon, L. (ed.). 1959. The Adams-Jefferson letters: The complete correspondence between Thomas Jefferson and Abigail and John Adams, vol. 2. Chapel Hill, NC: University of North Carolina Press.

Carter, I. 2011. Respect and the basis of equality. Ethics 121 (3): 538-571.

Carter, I. 2013. Basic equality and the site of Egalitarian Justice. Economics and Philosophy 29: 21-41.

Cohen, G. 1989. On the currency of egalitarian justice. Ethics 99: 906-944.

Cohen, J. 2009. Philosophy, politics, democracy: Selected essays. Cambridge, MA: Harvard University Press.

Constant, B. 1988. Constant: Political writings, ed. Biancamaria Fontana. Cambridge: Cambridge University Press.

Cupit, G. 2000. The Basis of Equality. Philosophy, 105-125. Cambridge: Cambridge University Press.

Dahl, R. A. 2006. On political equality. New Haven: Yale University Press.

Dworkin, R. 1977. Taking rights seriously. London: Duckworth.

Dworkin, R. 1981a. Is there a right to pornography? Oxford Journal of Legal Studies 1 (2): 201.

Dworkin, R. 1981b. What is equality? Part 1: Equality of welfare. Philosophy and Public Affairs 10: 185-246.

Dworkin, R. 1981c. What is equality? Part 2: Equality of resources. Philosophy and Public Affairs 10: 283-345.

Dworkin, R. 1983. Comment on Narveson: In defense of equality. Social Philosophy and Policy 1: 24-40.

Dworkin, R. 1985. A matter of principle. Cambridge, MA: Harvard University Press.

Dworkin, R. 2000. Sovereign virtue: The theory and practice of equality. Cambridge, MA: Harvard University Press.

Enoch, D. 2012. Against public reason. In Oxford studies in political philosophy, vol. 1, ed. David Sobel, Peter Vallentyne, and Steven Wall. Oxford: Oxford University Press. (Forthcoming).

Estlund, D. 2008. Democratic authority: A philosophical framework. Princeton: Princeton University Press.

Filmer, R. 1685. Patraricha or, The natural power of kings, 2nd edn, W. Chiswel, W. Hensman, M. Gilliflows, and G. Wells, London.

Gaus, J. 2015. Private and public conscience (Or, is the sanctity of conscience a liberal commitment or an anarchical fallacy?). In Reason, value and respect, ed. M. Timmons, and R. Johnson, 136-156. Oxford: Oxford University Press.

Goodman, L. E. 1976. Equality and Human Rights: The Lockean and the Judaic Views. Judaism 25: $325-362$.

Green, L. 2010. Two Worries about Respect for Persons. Ethics, 120: 212-331.

Griffin, J. 1986. Well-being: Its meaning, measure, and moral importance. New York, NY: Oxford University Press.

Gutmann, A. 1980. Liberal equality. Cambridge: Cambridge University Press.

Haksar, V. 1979. Equality, liberty and perfectionism. Oxford: Clarendon Press.

Haksar, V. 2003. Equality, liberty and perfectionism. In Perfectionism and neutrality: Essays in liberal theory, ed. S. Wall, and G. Klosko, 91-102. Oxford: Lanham.

Hare, R. M. 1981. Moral thinking: Its levels, methods and point. Oxford: Clarendon Press.

Harsanyi, J. C. 1982. Morality and the theory of rational behaviour. In Utilitarianism and beyond, ed. A. Sen, and B. Williams, 39-62. Cambridge: Cambridge University Press.

Held, D. 1996. Models of democracy, 2nd edn. Stanford, CA: Stanford University Press.

Hobbes, T. 1962. Leviathan. London: William Collins Sons \& Co.

Hurka, T. 1993. Perfectionism. Oxford: Oxford University Press.

Hutcheson, F. 1725. An inquiry into the original of our ideas of beauty and virtue, London; excerpts reprinted in Raphael, D. D. (1969). British Moralists. Oxford: Clarendon Press.

Isakhan, B., and S. Stockwell. 2011. The secret history of democracy. Basingstoke: Palgrave. 
Kant, I. 1996. Practical philosophy, tr. and ed. Gregor, M. J., Cambridge: Cambridge University Press. Kekes, J. 1990. Facing evil. Oxford: Oxford University Press.

Kymlicka, W. 2002. Contemporary political philosophy: An introduction, 2nd edn. Oxford: Oxford University Press.

Larmore, C. 1996. The morals of modernity. Cambridge: Cambridge University Press.

Larmore, C. 2008. The autonomy of morality. Cambridge: Cambridge University Press.

Lilburne, J. 1938. The free-man's freedom vindicated. In Puritanism and Liberty, ed. A. S. P. Woodhouse. London: J. M. Dent \& Sons Ltd.

Llyod Thomas, D. A. 1979. Equality within the limits of reason alone. Mind 88: 368-553.

Locke, J. 2003. Two treatises in government and a letter concerning toleration, ed. Shapiro, I. New Haven, CT: Yale University Press.

Lovejoy, A. O. 1953. The great chain of being: A study of the history of an idea. Cambridge, MA: Harvard University Press.

Lukes, S. 1977. Essays in social theory. London: Macmillan.

Macedo, S. 1990. Liberal virtues: Citizenship, virtue, and community in liberal constitutionalism. Oxford: Clarendon Press.

Mill, J. S. 1910. Utilitarianism, liberty, and representative government. London: J. M. Dent \& Sons Ltd. Miller, D. 2000. Citizenship and national identity. Cambridge: Polity Press.

Morgan, G. 1943. Human equality. Ethics 53: 115-120.

Nagel, T. 1987. Moral conflict and political legitimacy. Philosophy and Public Affairs 16 (3): 215-240.

Nagel, T. 1991. Equality and partiality. Oxford: Oxford University Press.

Nicholas of Cusa, De Concordantia Catholica, Bk. II.14. 1954. Medieval Political Ideas (trans: Ewart, L.), 192. London: Routledge \& Kegan Paul.

Nietzsche, F. 1968. The twilight of the idols and the antichrist. London: Penguin.

Nietzsche, F. 1974. The Gay Science, tr. Arnold Kaufman. New York, NY: Vintage Books.

Nozick, R. 1974. Anarchy, state, and utopia. New York, NY: Basic Books.

Nussbaum, M. 2011. Perfectionist liberalism and political liberalism. Philosophy and Public Affairs 39 (1): $3-45$.

Parfit, D. 1997. Equality and priority. Ratio 10 (3): 202-221.

Pettit, P. 2012. On the people's terms: A republican theory and model of democracy. Cambridge: Cambridge University Press.

Plato. 1892. The Dialogues of Plato, Vol III, 'The Republic', tr. by Jowett, B., Oxford: Clarendon Press.

Pojman, L. 1991. A critique of contemporary egalitarianism: A Christian perspective. Faith and Philosophy 8: 481-504.

Pojman, L. 1992. Are human rights based on equal human worth? Philosophy and Phenomenological Research 52: 117-128.

Pojman, L. 1997. On equal human worth: A critique of contemporary egalitarianism. In Equality, ed. L. Pojman, and R. Westmoreland, 282-299. New York, NY: Oxford University Press.

Pojman, L., and R. Westmoreland (eds.). 1997. Equality. New York, NY: Oxford University Press.

Pufendorf, S. 1994. The political writings of Samuel Pufendorf. Oxford: Oxford University Press.

Quong, J. 2010. Liberalism without perfection. Oxford: Oxford University Press.

Quong, J. 2011. Liberalism without perfection. Oxford: Oxford University Press.

Rashdall, H. 1924. The theory of good and evil: A treatise on moral philosophy, vol. 1, 2nd edn. London: Oxford University Press.

Rawls, J. 1971. A theory of justice. Oxford: Oxford University Press.

Rawls, J. 1980. Kantian constructivism in moral theory. Journal of Philosophy 77: 512-572.

Rawls, J. 1993. Political liberalism. New York, NY: Columbia University Press.

Raz, J. 1975. Practical reason and norms. Oxford: Oxford University Press. [reprint 1999].

Raz, J. 1979. The Authority of law: Essays on law and morality. Oxford: Clarendon Press.

Raz, J. 1986. The morality of freedom. Oxford: Clarendon Press.

Raz, J. 2006. The problem of authority: Revisiting the service conception. Minnesota La Review 90: 1003-1044.

Raz, J. 2010. On respect, authority, and neutrality: A response. Ethics 120 (2): 279-301.

Roemer, J. 1996. Theories of distributive justice. Cambridge, MA: Harvard University Press.

Rosen, M. 2012. Dignity: Its history and meaning. Cambridge, MA: Harvard University Press.

Rousseau, J.-J. 2004. The social contract, tr. Cranston, M. London: Penguin Books.

Ruskin, J. 2007. The stones of Venice, vol. 2: The Sea Stories. New York, NY: Cosimo.

Sabine, G. H. 1937. A history of political theory. London: George G. Harrap \& Co. Ltd. 
Santayana, G. 1905. Reason and society. New York, NY: Charles Scribner.

Scanlon, T. M. 2003. The difficulty of tolerance: Essays in political philosophy. Cambridge: Cambridge University Press.

Scanlon, T. M. 2004. When does equality matter? unpublished manuscript. http://www.law.yale.edu/ documents/pdf/Intellectual_Life/ltw-Scanlon.pdf.

Sen, A. 1992. Inequality reexamined. Oxford: Oxford University Press.

Sen, A. 2009. The idea of justice. London: Penguin Books.

Shapiro, T. 2002. John Locke's Democratic Theory. In Locke, J., Two treatises in government and a letter concerning toleration, ed. Shapiro, I., 309-340, New Haven, CT: Yale University Press.

Sigmund, P. E. 1967. Hierarchy, equality, and consent. In Equality, ed. J. R. Pennock, and J. W. Chapman, 134-153. New York, NY: Atherton Press.

Singer, P. 1977. Animal liberation. Frogmore: Granada Publishing.

Smith, N. 2011. Basic equality and discrimination: Reconciling law and practice. Farnham: Ashgate.

Somjee, A. H. 1967. Individuality and equality in Hinduism. In Equality, ed. J. R. Pennock, and J. W. Chapman, 154-176. New York, NY: Atherton Press.

Spiegelberg, H. 1944. A defense of human equality. The Philosophical Review 53: 101-124.

Steiner, H. 1994. An essay on rights. Oxford: Blackwell.

Stemplowska, Z. 2011. Holding people responsible for what they do not control. Politics, Philosophy and Economics 7: 355-377.

Vlastos, G. 1984. Justice and equality. In Theories of rights, ed. Jeremy Waldron, 41. Oxford: Oxford University Press.

Waldron, J. (ed.). 1993. Theoretical foundations of liberalism. In Liberal rights: Collected papers 19811991. Cambridge: Cambridge University Press.

Waldron, J. 1999. Law and disagreement. Oxford: Clarendon Press.

Waldron, J. 2008. Basic equality. In New York University Public Law and Legal Theory Working Papers, Paper 107. http://lsr.nellco.org/nyu_plltwp/107.

Waldron, J. 2011. Does "Equal Moral Status” Add Anything to Right Reason? In New York University Public Law and Legal Theory Working Papers, Paper 292. http://lsr.nellco.org/nyu_plltwp/292.

Wall, S. 1998. Liberalism, Perfectionism and Restraint. Cambridge: Cambridge University Press.

Wasserstrom, R. 1971. Rights, human rights, and racial discrimination. In Moral problems, 2nd edn. ed. James Rachels. New York, NY: Harper and Row.

White, S. 1997. Equality. Cambridge: Polity Press.

Williams, B. 1973. The idea of equality. In his Problems of the self, 230-249. Cambridge: Cambridge University Press.

Williams, B. 1981. Moral luck. Cambridge: Cambridge University Press.

Wolff, R. 1970. In defense of anarchism. Berkeley, CA: University of California Press.

Wolff, J. 2012. Scanlon on social and material inequality. Journal of Moral Philosophy 10 (4): 406-425.

Wollheim, R. 1962. A paradox in the theory of democracy. In Philosophy, politics and society, 2nd edn. ed. P. Laslett, and W. G. Runciman. Oxford: Blackwell.

Woodhouse, A. (ed.). 1951. Puritanism and liberty: Being the Army debates (1647-9) from the Clarke manuscripts with supplementary documents. London: J. M. Dent \& Sons Ltd.

Yeats, W. B. 1992. Collected poems. London: Vintage. 